Jillian Collier

\title{
Pick your battles \\ Re-examining the Framework for community colleges
}

In nformation literacy is a valued skill in almost every academic discipline, and increasingly valued by employers in the workforce. ${ }^{1}$ This point is of particular interest to librarians and faculty at community colleges, where job-ready skills and practical concepts are the priority for our students. However, reception of the ACRL Framework for Information Literacy for Higher Education has been lukewarm among community college librarians. Many librarians who work in community colleges believe the Framework is meant for four-year schools and researchbased institutions. By closely re-examining the Framework and recognizing student needs, community college librarians can use the Framework much more effectively.

\section{Why it matters so much for community colleges}

The American Association of Colleges and Universities (AAC\&U) has commissioned several studies over recent years to track and analyze the connections between what students are learning in college ${ }^{2}$ and what they will need to succeed when they graduate. This research is especially helpful for community colleges, where the majority of students are directly focused on a specific career goal.

For one of these studies, published in 2010, employers were asked about their perceptions of the information literacy skills that college graduates entering the workforce needed to improve. Eighty-one percent of employers said that college graduates would be better prepared for success in the workplace if they "develop the skills to research the questions in their field and develop evidence-based analyses." 3

A similar study from 2015 reported that $68 \%$ of employers agree that information literacy is a skill that every student should acquire, no matter in which field they plan to work. ${ }^{4}$ This data shows that the need for graduates to be information literate is consistent and important for workplace success. One study recognized that employers seek employees who can effectively engage with information. ${ }^{5}$ The same study concluded that while the Framework's current set of concepts is too confined and academic, the "notion of employing threshold concepts to help students evolve their knowledge and skills over time seems favorable."

To meet this need, community college librarians must continually improve our information literacy instruction, and engaging with the Framework is the best way to do that.

\section{The Framework in community college libraries}

Engagement with the Framework, however, has been unenthusiastic among community college librarians. According to a

Jillian Collier is public services librarian at Spartanburg Community College, email: collierj@sccsc.edu

(C) 2019 Jillian Collier 
recent survey, "only eleven percent of respondents strongly agree with the statement: 'I am very familiar with the frames, knowledge practices and dispositions in the ACRL Framework'"' ${ }^{7}$ and only 37 percent say that it is "easy to integrate" into community college instruction. ${ }^{8}$ Open-ended responses from the same survey included no positive comments on the Framework's relevance to community college campuses specifically. ${ }^{9}$

This perceived lack of relevance is one reason that some community college librarians have been reluctant to fully engage with the Framework for planning and assessing information literacy instruction. The threshold concepts and knowledge practices used in the Framework have been described as "wordy, confusing, and irrelevant to the work done by community college students," ${ }^{10}$ making it difficult to use the frames as a guide with students and with faculty. This is a fair criticism of the Framework, but not a good reason to disengage from it completely.

It is the responsibility of librarians, as experts in this space, to interpret the frames, choose the most relevant ones, and share them with campus communities in ways that make sense. The text of the Framework gives us license to use it as we see fit.

A close reading of the Framework's first appendix reveals this nugget of advice: "ACRL encourages information literacy librarians to be imaginative and innovative in implementing the Framework at their institution. The Framework is not intended to be prescriptive, but to be used as a guiding document." ${ }^{11}$ In other words, do what makes sense based on the needs and priorities of any given institution, using the Framework as a general guide. It is a mistake to assume that the Framework must be followed to the letter. It is more fluid than a set of standards, and that's okay.

When it comes to assessment of information literacy instruction, many community college librarians have found the fluidity of the Framework to be challenging. The lan-

\section{It is the responsibility of librarians, as experts in this space, to interpret the frames, choose the most relevant ones, and share them with campus communities in ways that make sense. The text of the Framework gives us license to use it as we see fit.}

guage of the frames, knowledge practices, and dispositions do not prescribe specific learning outcomes to assess. Instead, the Framework uses "terms like understand, recognize, and value, as opposed to the action verbs that we know work well when writing learning outcomes-words like determine, access, evaluate, and use."12 Again, the Framework is giving us license to create our own instruction and to write learning outcomes based on the concepts and skills that we determine are most relevant to our students.

For example, if you were teaching a oneshot information literacy instruction session focused on the threshold concept of Authority is Constructed and Contextual, one of the knowledge practices for that concept is to "recognize that authoritative content may be packaged formally or informally and may include sources of all media types."13 This concept could easily be adapted into an assessable learning outcome with action verbs such as: determine authoritative content and nonauthoritative content from different media types or evaluate the authority of formally and informally packaged content.

I recommend using the Framework's knowledge practices and dispositions as a guide to composing assessable learning outcomes for information literacy instruction. This method can combine the concepts from the Framework with librarians' specific needs or teaching styles to create effective and engaging instruction for students.

Another criticism of the Framework from community college librarians is the broad scope of the threshold concepts. Informa- 
tion literacy encompasses numerous skills and concepts, and so does the Framework. But, some community college librarians have felt "overwhelmed by it." ${ }^{14}$ At my institution, most of our instruction is usually in the form of one-shots, giving us limited time with students to appropriately address numerous concepts. Not only that, most of our students are only with us for two years. In that time, they are inundated with new knowledge and experiences from their general education courses and have precious little headspace for information literacy to sink into.

If we as librarians feel overwhelmed by the scope of information literacy concepts, students will feel even more so. This is why the Framework itself recommends picking your battles, choosing the threshold concepts and skills that are most relevant to your students at the time that you are with them. Again, from Appendix 1:

It is important for librarians and teaching faculty to understand that the Framework is not designed to be implemented in a single information literacy session in a student's academic career; it is intended to be developmentally and systematically integrated into the student's academic program at a variety of levels ... the frames are intended to demonstrate the contrast in thinking between novice learner and expert in a specific area; movement may take place over the course of a student's academic career. Mapping out in what way specific concepts will be integrated into specific curriculum levels is one of the challenges of implementing the Framework. ${ }^{15}$

This description clarifies that librarians should not worry about fitting everything into a one-shot. And, community college librarians should perhaps not even worry about fitting everything into two years. What it does recommend is that librarians fit in the concepts that are relevant to students and their work at their specific curriculum level, trusting that when they reach a different curriculum level, there will be a librarian there to pick up where the last left off. Transfer students need to be able to continue learning information literacy skills at a four-year school using the same conceptual Framework that they were introduced to in community college.

For our students who are entering the workforce, and not continuing to a higher curriculum level, we need to pick our battles and make sure we are empowering them with the concepts, skills, and knowledge that will serve them best in their careers. So far, community college librarians have shown a willingness to focus on certain frames more than others during information literacy instruction.

According to Susan T. Wengler and Christine Wolff-Eisenberg's survey, Searching as Strategic Exploration, Research as Inquiry, and Information Has Value are the most important threshold concepts in community college library instruction. ${ }^{16}$ This makes perfect sense, especially keeping in mind the results of the aforementioned studies commissioned by AAC\&U, where employers said they wanted college graduates who could use research to answer questions and solve problems in their field of work.

Understanding the value of information, recognizing the research process as inquiry, and knowing that searching for the answer to a question is a strategic exploration of information are all very practical skills that could be transferred into many different career fields, from health sciences to the humanities. On the other hand, Scholarship as Conversation might not be very relevant to students who are not interested in graduate school or a career in academia.

It is great to see community college librarians engaging with the Framework in this way, and we are encouraged to do this even more. According to the Frame- 
work itself, this is one of the ways that it was intended to be used-as a guide to designing information literacy instruction that can start with novice learners at the threshold of a concept and build with them over time until they become empowered with the information literacy skills they need for success.

\section{Conclusion}

Community college librarians have many criticisms of the ACRL Framework for Information Literacy for Higher Education, and many of them are fair. The scope of all six threshold concepts is very large, the language is sometimes vague, and the relevance of each concept may vary by institution. However, these criticisms are not reasons to abandon the Framework. They are reasons to engage with it.

The Framework allows for flexibility in how it is implemented. For community colleges, this flexibility can be used to create library instruction that focuses on job-ready information literacy skills, while keeping the broad concepts of information literacy in mind. I encourage this approach because it is crucial for community college students to be prepared for workplace success, but it is also important that they be prepared for further development of their information literacy knowledge.

Community college graduates will continue to learn information literacy skills on the job or when they transfer to a four-year institution. Community college librarians can help their students be prepared for any path they choose by using the Framework in a creative and customized way. I also encourage community college librarians to do this work in creative and collaborative ways. For some, professional development with the Framework may be needed. For others, what's needed may be time to spend developing new instruction plans.

Work with your colleagues and campus partners to find what works for you and your students, pick your battles and win using the Framework as a guide.

\section{Notes}

1. Liberal Education and America's Promise, "Employer Priorities for Most Important College Learning Outcomes," Association of American Colleges \& Universities, https://www.aacu.org/ leap/public-opinion-research/2015-employerpriorities (accessed June 27, 2019).

2. Hart Research Associates, "Raising the Bar: Employers' Views on College Learning in the Wake of the Economic Downturn," Association of American Colleges and Universities, https://www.aacu.org/sites/default /files/files/LEAP/2009_EmployerSurvey.pdf (accessed June 27, 2019).

3. Ibid., 8.

4. LEAP, "Employer Priorities."

5. Megan E. Dempsey, Heather Dalal, Lynee R. Dokus, Leslin H. Charles, and Davida Scharf, "Continuing the Conversation: Questions about the Framework," Communications in Information Literacy, 9, no. 2 (2015): 172, https://doi.org/10.15760 /comminfolit.2015.9.2.193.

6. Ibid.

7. Susan T. Wengler, and Christine WolffEisenberg, "Community College Librarians and the ACRL Framework: Findings from a National Study," College \& Research Libraries, in press: preprint, 11, https://academicworks.cuny.edu/qb_pubs/56/.

8. Ibid., 19.

9. Ibid., 12.

10. Dempsey, et al, "Continuing the Conversation," 167.

11. ACRL, "Framework for Information Literacy for Higher Education," 25, http:// www.ala.org/acrl/sites/ala.org.acrl/files /content/issues/infolit/Framework_ILHE. pdf (accessed June 27, 2019).

12. Dempsey, et al, "Continuing the Conversation," 168.

13. ACRL, "Framework," 13.

14. Wengler and Wolff-Eisenberg, "Community College Librarians and the ACRL Framework," 11.

15. ACRL, "Framework," 25.

16. Wengler and Wolff-Eisenberg, "Community College Librarians and the ACRL Framework," 13. 